Editorial

\title{
Beyond Foreign Policy? EU Sanctions at the Intersection of Development, Trade, and CFSP
}

\author{
Katharina L. Meissner ${ }^{1, *}$ and Clara Portela ${ }^{2}$ \\ ${ }^{1}$ Centre for European Integration Research (EIF), University of Vienna, Austria \\ ${ }^{2}$ Faculty of Law, University of Valencia, Spain \\ * Corresponding author (katharina.meissner@univie.ac.at)
}

Submitted: 19 November 2021 | Published: 26 January 2022

\begin{abstract}
In the wake of unsettling conflicts and democratic backsliding, states and organisations increasingly respond with sanctions. The European Union (EU) is one of them: Brussels makes use of the entire toolbox in its foreign policy, and its sanctions appear in different forms-diplomatic measures, travel bans, financial bans, or various forms of economic restrictions. Yet, there is little debate between different strands in the literature on EU sanctions, in particular concerning measures under the Common Foreign and Security Policy and those pertaining to the development and trade policy fields. Our thematic issue addresses this research gap by assembling a collection of articles investigating the design, impact, and implementation of EU sanctions used in different realms of its external affairs. Expanding the definition of EU sanctions to measures produced under different guises in the development, trade, and foreign policy fields, the collection overcomes the compartmentalised approach characterising EU scholarship.
\end{abstract}

\section{Keywords}

Common Foreign and Security Policy; conditionality; development cooperation; European Union; restrictive measures; sanctions; trade

\section{Issue}

This editorial is part of the issue "Beyond Foreign Policy? EU Sanctions at the Intersection of Development, Trade, and CFSP" edited by Katharina Meissner (University of Vienna) and Clara Portela (University of Valencia).

(C) 2022 by the author(s); licensee Cogitatio (Lisbon, Portugal). This editorial is licensed under a Creative Commons Attribution 4.0 International License (CC BY).

Not only has the European Union (EU) long been at the forefront of including conditionality clauses in its international agreements, but sanctions have become an important tool in its external relations in the wake of unsettling conflicts in its neighbourhood (Portela, 2017; Richter \& Wunsch, 2020). Yet, while this has led to increased scholarly attention to the EU as a sanctions sender (Giumelli, 2011; Kreutz, 2015), two key deficits can still be identified.

Firstly, recent research identifies the design of sanctions to be central to their outcomes (McLean \& Whang, 2014). Understanding drivers of sanctions' design is important from an analytical and policy perspective. From an analytical viewpoint, most research on restrictive measures examines their (in-)effectiveness and con- sequences for target states (Hufbauer et al., 2007), while neglecting how this is linked to their design and the drivers of different options (McLean \& Whang, 2014; Portela, 2016). Hence, there is a lack of fine-grained investigation into the design of EU sanctions, what factors motivate such decisions, and what impact specific designs have. To date, scholars have provided no systematic investigation into the design of EU restrictive measures.

Secondly, the overwhelming focus on sanctions adopted under the Common Foreign and Security Policy (CFSP) that prevails in European studies translates into little awareness that EU sanctions appear in different designs. Sanctions encompass diplomatic measures, travel bans, financial bans, and various forms 
of economic restrictions (Drury, 2001). Few research attempts to bridge research traditions between CFSP measures, on the one hand, and trade and development policy (Koch, 2015; Meissner, 2021; Portela, 2010), on the other-let alone other sanctioning measures like the Treaty on EU (TEU) Article 7 (Hellquist, 2019) or conditionality in enlargement policy.

Our thematic issue seeks to remedy this double research gap by investigating systematically the design of EU sanctions used in its external affairs. We understand sanctions broadly as a "temporary abrogation of normal state-to-state relations to pressure target states" (Tostensen \& Bull, 2002, p. 374). Hence, our understanding of sanctions is indiscriminate to the target's location-within or outside the EU-as well as to the measures abrogating "normal" relations. Sanctions, according to our definition, cover CFSP restrictions, conditionality clauses, aid freezes, withdrawal of trade preferences for political reasons, diplomatic sanctions, and measures under Article 7 TEU. In this sense, our conceptualization of sanctions goes beyond the narrowlydefined CFSP area and extends to development and trade policy (Meissner \& McKenzie, 2018). The issue is, thus, innovative in that it overcomes the compartmentalised approach that EU scholarship has displayed so far, with development researchers looking into aid suspensions, trade researchers considering conditionality in international agreements, and international security scholars analysing CFSP sanctions.

Kim Olsen opens our collection by situating sanctions in the context of geo-economics and by conceptualizing sanctions as one ingredient of EU geo-economics diplomatic capabilities (Olsen, 2022). Olsen's endeavour rests on the observation that the EU has recently made a more assertive use of economic power in its external affairs, epitomised in Commission President Ursula von der Leyen's emphasis on the need for a new geo-economic approach for the EU's role in the world. Olsen presents sanctions as "policy tools situated at the intersection between the spheres of states and markets" (Olsen, 2022 , p. 12). While Olsen considers sanctions as a tool within a range of multiple geo-economic instruments, Giselle Bosse explores the moral dimension of EU authority to employ sanctions (Bosse, 2022). In particular, in the absence of a United Nations Security Council mandate, Bosse argues that EU unilateral actions require moral authority. Drawing on Habermas' theory of communicative action, Bosse develops a framework for assessing the substantive and procedural standards of moral authority which she then applies to the case of CFSP restrictive measures imposed on Uzbekistan in 2005.

The following contribution explores specific designs of CFSP restrictive measures and their impacts. Focusing on asset freezes and visa bans, two recurrent types of CFSP sanctions, Clara Portela and Thijs Van Laer tackle the unexplored question whether the impact of listings on designees corroborates the EU's initial targeting choices (Portela \& Van Laer, 2022). Relying on a unique set of interviews with sanctions designees, Portela and Van Laer investigate this question empirically in the cases of Côte d'Ivoire and Zimbabwe. Francesco Giumelli, Willem Geelhoed, Max de Vries, and Aurora Molesini shed light on sanctions' implementation by EU member states and the degree to which they conform to coherent national laws and enforcement (Giumelli et al., 2022). While researchers had identified the potential for variation in the implementation of sanctions across the EU (Druláková \& Přikryl, 2016; Helwig et al., 2020; Meissner \& Urbanski, 2021), no systematic study had yet been conducted on the transposition and application of restrictive measures within the EU. Interestingly, the authors find significant variation on how EU member states implement CFSP sanctions - a result which calls for further research.

In addition to CFSP, trade policy provides an important area of EU sanctions. Two trade policy tools for sanctioning third states are the Generalised Scheme of Preferences (GSP) and international trade agreements. Arlo Poletti and Daniela Sicurelli investigate the "negative case" Myanmar (2018), problematizing the Council's inaction in the face of Myanmar's Rohingya crisis despite vocal calls by the European Parliament and non-governmental organizations to withdraw tariff preferences (Poletti \& Sicurelli, 2022). Adopting a political economy approach, the authors explain the Council's decision not to withdraw the GSP with the prevalence of European economic operators' interests in stable trade relations with Myanmar. María García studies the sanctioning options embedded in the new Trade and Sustainable Development (TSD) chapters for labour and environmental matters included in the EU's international trade agreements (García, 2022). Conditionality clauses in TSD chapters aim to ensure specific human and labour rights and environmental standards. While one way of enforcing these rights and standards is the use of conditionality clauses, García explores a second way of enforcing labour rights and environmental matters through the dispute settlement mechanisms. Analysing these dynamics in the EU-Korea preferential trade agreement, García shows that the TSD chapters and the dispute settlement mechanism are potentially strong tools to promote labour and environmental norms.

Jan Orbie, Antonio Alcazar, and Tinus Sioen take a post-development perspective on how the EU uses its trade policy to sanction third countries (Orbie et al., 2022). In particular, the authors problematize the GSP scheme with which certain human rights, labour norms, and environmental standards are pursued and the discourse adopted by EU elites. Shedding light on the GSP from a post-development perspective, they show how the discourse of EU elites and in Cambodia and the Philippines reinforces the hierarchical concepts of "developed" and "developing" countries.

In the concluding contribution, Johanne Saltnes and Martijn Mos suggest an integrated perspective on the EU's sanctioning tools by considering "material" 
sanctions in addition to "social" sanctions (Saltnes \& Mos, 2022). By social sanctions, the authors mean a naming and shaming of wrongdoings but also diplomatic endeavours like dialogue. With such an encompassing approach, Saltnes and Mos advocate that the non-adoption of "material" sanctions does not equal inaction but may imply the use of alternative tools such as "social" sanctions. The authors investigate the range of EU responses to LGBTI rights violations in Lithuania and Uganda.

With this rich collection of articles, produced by a gender-balanced group of scholars from eight nationalities, often co-authoring in cross-national partnerships, we hope to foster the exploration of both the multifaceted design of various forms of EU sanctions and their interlinkages.

\section{Acknowledgments}

This work was supported by the Austrian Science Fund (FWF) [grant number M-2573].

\section{Conflict of Interests}

The authors declare no conflict of interests.

\section{References}

Bosse, G. (2022). Does the EU have moral authority? A communicative action perspective on sanctions. Politics and Governance, 10(1), 16-25.

Druláková, D., \& Přikryl, P. (2016). The implementation of sanctions imposed by the European Union: A comparison of the Czech and Slovak Republics. Central European Journal of International \& Security, 10(1), 134-160.

Drury, A. C. (2001). Sanctions as coercive diplomacy: The U.S. President's decision to initiate economic sanctions. Political Research Quarterly, 54(3), 485-508.

García, M. J. (2022). Sanctioning capacity in trade and sustainability chapters in EU trade agreements: The EU-Korea case. Politics and Governance, 10(1), 58-67.

Giumelli, F. (2011). Coercing, constraining and signalling: Explaining UN and EU sanctions after the Cold War. ECPR Press.

Giumelli, F., Geelhoed, W., de Vries, M., \& Molesini, A. (2022). United in diversity? A study on the implementation of sanctions in the European Union. Politics and Governance, 10(1), 36-46.

Hellquist, E. (2019). Ostracism and the EU's contradictory approach to sanctions at home and abroad. Contemporary Politics, 25(4), 393-418.

Helwig, N., Jokela, J., \& Portela, C. (2020). EUSanktionspolitik in geopolitischen Zeiten: Europas schärfstes Außeninstrument und seine Herausforderungen [EU sanctions policy in geopolitical times. Europe's sharpest tool and its challenges]. integration, 43(4), 278-294.

Hufbauer, G., Schott, J., Elliott, K., \& Oegg, B. (2007). Economic sanctions reconsidered. Peterson Institute for International Economics.

Koch, S. (2015). A typology of political conditionality beyond aid: Conceptual horizons based on lessons from the European Union. World Development, 75, 98-108.

Kreutz, J. (2015). Human rights, geostrategy, and EU foreign policy, 1989-2008. International Organization, 69(1), 195-217.

McLean, E. V., \& Whang, T. (2014). Designing foreign policy: Voters, special interest groups, and economic sanctions. Journal of Peace Research, 51(5), 589-602.

Meissner, K. L. (2021). Requesting trade sanctions? The European Parliament and the Generalised Scheme of Preferences. Journal of Common Market Studies, 59(1), 91-107.

Meissner, K. L., \& McKenzie, L. (2018). The paradox of human rights conditionality in EU trade policy: When strategic interests drive policy outcomes. Journal of European Public Policy, 26(9), 1273-1291.

Meissner, K. L., \& Urbanski, K. (2021). Feeble rules: One dual-use sanctions regime, multiple ways of implementation and application? European Security. Advance online publication. https://doi.org/ 10.1080/09662839.2021.1993189

Olsen, K. (2022). Diplomatic realisation of the EU's "geoeconomic pivot": Sanctions, trade, and development policy reform. Politics and Governance, 10(1), 5-15.

Orbie, J., Alcazar III, A. S. M., \& Sioen, T. (2022). A postdevelopment perspective on the EU's generalized scheme of preferences. Politics and Governance, 10(1), 68-78.

Poletti, A., \& Sicurelli, D. (2022). The political economy of the EU approach to the Rohingya crisis in Myanmar. Politics and Governance, 10(1), 47-57.

Portela, C. (2010). European Union sanctions and foreign policy. Routledge.

Portela, C. (2016). Are European Union sanctions "targeted"? Cambridge Review of International Affairs, 29(3), 912-929.

Portela, C. (2017). Sanctions and the European neighbourhood policy. In T. Schumacher, A. Marchetti, \& T. Demmelhuber (Eds.), Routledge handbook on the European neighbourhood policy (pp. 270-278). Routledge.

Portela, C., \& Van Laer, T. (2022). The design and impacts of individual sanctions: Evidence from elites in Côte d'Ivoire and Zimbabwe. Politics and Governance, 10(1), 26-35.

Richter, S., \& Wunsch, N. (2020). Money, power, glory? The linkage between EU conditionality and informal politics in the Western Balkans. Journal of European Public Policy, 27(1), 41-62.

Saltnes, J. D., \& Mos, M. (2022). Understanding the EU's response to LGBTI rights violations: Inter-institutional 
differences and social sanctions. Politics and Governance, $10(1), 79-89$.
Tostensen, A., \& Bull, B. (2002). Are smart sanctions feasible? World Politics, 54(3), 373-403.

\section{About the Authors}

Katharina L. Meissner (PhD) is postdoc and project leader (FWF M-2573) at the Centre for European Integration Research (EIF), Department of Political Science, University of Vienna. She holds a PhD in political and social sciences from the European University Institute (EUI), Florence, Italy.

Clara Portela (PhD) is professor of political science at the Law School of the University of Valencia, having previously served as a professor at Singapore Management University and as a research fellow with the Institute for Security Studies of the European Union in Paris. She holds a PhD from the European University Institute (EUI) in Florence and an MA from the Free University of Berlin. 